International Journal of Instruction e-ISSN: 1308-1470 • www.e-iji.net

Article submission code: 20201111100310

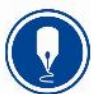

October $2021 \bullet$ Vol.14, No.4

p-ISSN: 1694-609X

pp. 567-584

Received: 11/11/2020

Revision: 05/04/2021
Accepted: 29/04/2021

OnlineFirst: 11/08/2021

\title{
Incorporating Village Tourism into "Community Economy" Course: A Project-Based Learning Method in University
}

\section{Kiromim Baroroh}

Doctoral Student of Universitas Negeri Malang, Lecturer in Universitas Negeri Yogyakarta, Indonesia, kiromim_b@uny.ac.id

\section{Wahjoedi}

Universitas Negeri Malang, Indonesia, wahjoedi.fe@um.ac.id

\section{Hari Wahyono}

Universitas Negeri Malang, Indonesia, hari.wahyono.fe@um.ac.id

\section{Sugeng Hadi Utomo}

Universitas Negeri Malang, Indonesia, sugeng.hadi.fe@um.ac.id

\section{Febriyanti Lestari}

Sunan Kalijaga State Islamic University Yogyakarta Indonesia febriyanti.dl@uin-suka.ac.id

Village tourism is a type of tourism which integrates nature, culture, education, and the active participation of the local. It is intended to improve the community's prosperity. This model aligns with the Community Economy (CE) concept which advocates for people's well-being. This paper aims to describe the ways in which village tourism is incorporated in a CE course in economics department using problem-based learning (PBL) method and explore the development of students' characteristics out of the learning process. The subjects of this research were 3 lecturers and 90 students from a state university and a private university in Indonesia. The research design was mixed research. The data collection techniques include observation, interview, and documentation. The research results show that 1) village tourism condition can be integrated into themes related to $C E$ materials such as CE's basic concept, development model, policy, strategy, and partnership, society's empowerment, cooperative and micro small-medium enterprise, poverty alleviation, and 2) student's characteristics developed during the project. The researchers set some criteria to be observed: nationalistic, hardworking, creative, environmentally conscious, independent and cooperative, and after the observation, this research found that there was an increase in all these criteria. PBL encourages students to develop villages in Indonesia and find ways to increase national income and create sustainable development.

Keywords: village tourism, Community Economy, problem-based learning, character building, learning

Citation: Baroroh, K., Wahjoedi., Wahyono, H., Utomo, S. H., \& Lestari, F. (2021). Incorporating village tourism into "community economy" course: A project-based learning method in university. International Journal of Instruction, 14(4), 567-584. https://doi.org/10.29333/iji.2021.14433a 


\section{INTRODUCTION}

Tourism is one of the key factors in economic growth. Various studies indicate the positive impacts of tourism towards the economic growth in some countries, such as Latin America (Eugenio-Martin, 2004), Costa Rica (Jacobson \& Robles, 1992), Indonesia (Nizar, 2011) and South Africa (Fayissa et al., 2007; Phiri, 2016). The number of village tourism in Indonesia is currently on the rise due to the continuous development of various types of tourism. In Yogyakarta, for example, the number of tourist villages rose from 80 in 2014 to 135 villages in 2020 (Bapeda, 2021).

Rural tourism and village tourism are synonymous. This paper focuses on village tourism and the role of higher education in the development of this type of tourism. The involvement of a higher education institution is channeled through the principle of tridarma: education, research, and community service. In this way, knowledge development must be integrated with the needs of the community. In the field of tourism, the university's involvement can be viewed as a required sub-element for sustainable village tourism (Romadhon, 2013; Satria, 2009). Village tourism has significantly increased local income in China (Shuqiang, 2009), optimized the structure of village industry in China (Zhang, 2012), eliminated poverty in Iran (Aref \& Gill, 2009), and contributed to sustainable development in Romania (Dorobantu \& Nistoreanu, 2012).

Though tourism provided several positive impacts, the activities related to tourism could also bring negative impacts. For examples, environmental damage (Limbong \& Soetomo, 2013) economic loss (Wang, 2020) if the local people are not well trained in tourism industry, and social disadvantages such as population density, decreasing quality of life and cultural degradation (Schneider, 1993; Hayati, et.al., 2020).

The university should function not only to provide learning opportunities but also to stimulate innovation and solution for sustainable village tourism (Carlisle, et.al 2013). One of the potential courses to address this issue is Community-Economy (CE).

Community Economy creates vibrant sustainable local economies. The purpose of learning CE for students of higher education is to acquire values of economic democracy that ensures every citizen to actively participate in the economy regardless of social status, race, sex, etc. (Johanisova \& Wolf,2012). CE gets its hand on uncertain and complex economic problems and thus contributes to a kind of political economy of which will be supported by the ecological economy (Akbulut \& Adaman 2020). Moreover, CE is compatible with the universally accepted substantive democracy (Couret-Branco, 2016), and in its implementation, it must ensure an economy of, by, and for the people.

To date, CE courses mainly use textbooks as learning materials and resources. Learning activities are mostly conducted in classroom using several types of cooperative learning methods, such as Teams Game Tournament (TGT), and Student Team Achievement Division (STAD) role playing (Baroroh, et al., 2011). The learning resources are textbooks and exhibition. However, these learning resources and methods are still 
unable to precisely prescribe solutions to solve the existing problems in the community. It is suggested that students should broaden their knowledge with a variety of other learning resources (Wijiningsih et al.,2017) such as fieldwork in tourist village.

Direct observation to tourist villages can be considered as the learning resources in studying CE. The co-management concept of village tourism aligns with the "triple co" (co-ownership, co-determination, and co-responsibility) concept (Swasono 2018).

The students enrolled in CE courses need to carry out some planning, implementation, and evaluation in village tourism which stimulates important local economies. This paper argues that this kind of observation project will both enhance students' interests in CE courses and build students' characteristics in terms of nationalism, hardworking ethos, creativity, environmental awareness, independence and cooperation

In Indonesia, research on village tourism has been conducted by Rahmatullah (2016) while research on CE has been conducted by Wulandari, et al. (2017). PBL has been studied by many scholars such as Guo, et al., (2020), Parrado-Martínez, \& SánchezAndújar (2020). However, none of those incorporated CE courses in village tourism using PBL method.

The purposes of this study are (1) to explore the ways in which village tourism is incorporated into $\mathrm{CE}$ courses in an undergraduate education and (2) to examine how students develop their characteristics after their involvement in the project.

\section{Literature Review}

\section{Community Economics and Tourism Village}

The teaching and learning model of CE courses in universities across Indonesia varies. For example, it is taught through a course at the study center in Gadjah Mada University (UGM). In Malang State University (UM), CE is amongst options of concentration in the Development Economics Study Program. Meanwhile, at UNY, it is taught as a compulsory course with 2 credits. The subjects studied at UM are CE, microfinance, policies of community economic development, $\mathrm{CE}$ management, $\mathrm{CE}$ in practices, and seminar on CE (Wulandari, et al, 2017).

The term "CE" in the Indonesian language is "ekonomi kerakyatan" or civics economy, which is a new concept in economics. This term is also translated as "democratic economy" (Mubyarto, 2005). However, this research prefers to use the term "community economy" which was coined by Mit Wicaksono and popularized by Wulandari (2017) because this term is inherent with community economic development and is based on the fourth article of Pancasila that promotes an economy of "from, by, and for the people.

The principle of $\mathrm{CE}$ is the production by everyone, for everyone, and under the ownership of everyone (Awang et.al., 2012; Swasono, 2019). This also applies to the concept of village tourism that enables local people to equally obtain national welfare (Putri, et.al, 2019, Herawati, et.al, 2018, Arida, et.al,2019, Boy, 2019). One indicator in the $\mathrm{CE}$ is co-ownership which arises in co-management. Co-management is defined as the division of power and responsibilities in the use of resources between the central and 
local governments (Berkes, 2009). Co-management is necessary in administering village tourism (Romadhon, 2013). Furthermore, the implementation of co-management is not only about power-sharing and responsibility but also about cooperation, participation, the advancement of local knowledge, and the use of both traditional and scientific knowledge on ecology (Miller et al, 2010; Hermawan, 2016).

Previous studies on village tourism focused on the following issues. First, local economy-based strategies for ecotourism development becomes part of the poverty alleviation program (Satria, 2009). The findings point out the importance of a collaboration with Student Association for Nature Lovers in order to elicit creative ideas to develop ecotourism. Second, a model of socio-cultural and environmental wisdombased sustainable ecotourism in tourist village may serve as the guidelines for the government in making policies on sustainable tourism and regional economic independence (Haryanto, 2014). Third, in the field of education, a module with projectbased learning approach about ecotourism in coastal areas and oceans was developed in Universitas Negeri Malang for tourism geography course (Syafiudin, et.al., 2016). Fourth, it is suggested that the teacher should recommend the students to broaden their knowledge by learning from external resources such as TV, internet, and tourist village (Wijingsih, et al. 2017). For the teachers, it is advised that the teaching materials include the topic that raise environmental awareness. Fifth, a character-based eco-culture from the perspective of Pancasila economics was developed (Rahmatullah, 2016). Pancasila is Indonesia's national guiding principle (Agussalim, et.al, 2021). Sixth, environmental education to the important segment of Costa Rica local people who traditionally are not covered by schools or government development projects had been provided (Jacobson and Robles, 1992), but their education model was informal. On the contrary, this research is focused on formal education at the university level.

\section{PBL and Character Building}

One of the learning processes that can be done to understand village tourism is through PBL. The strength of this method is its ability to improve student's achievement (Doppelt, 2003). Combined PBL and community research to enhance the student's learning process has been conducted and it was found that this combined methods by allowing students to learn by doing while still being supervised by the professor and supported by the community can be a substantial and meaningful experience for the students. (Arantes do Amaral \& Rodrigues,-2018). It is particularly to increase student's motivation. The findings of research by Perrault \& Albert (2018) indicated that the implementation of PBL may lead to positive changes in student's attitudes such as severity, environmental awareness, self-efficacy, respond-efficacy, and intention to behave sustainably in the future. To sum up, PBL can be combined with other learning methods and may affect the development of students' characteristics. Nowadays, education is focused on making students more active and sensitive during the collaborative learning process (Kolesnikova, et al., 2020). PBL has the potential to build characteristics such as nationalistic, hard-working, creative, and environmentally conscious (Rina., et al., 2018; Nurtanto, et al., 2020).

The explanation above can be illustrated in a chart as follow: 


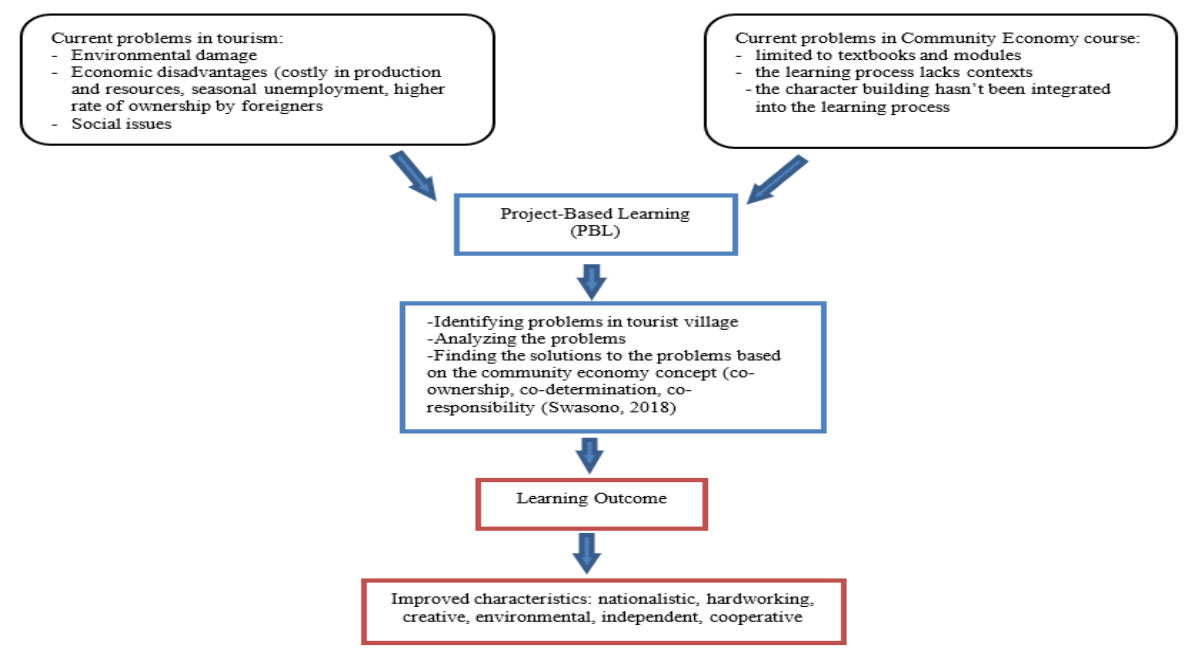

Figure 1

The conceptual framework

Incorporating village tourism into CE courses is important because students should be encouraged to care about the development of village in Indonesia. That way, they need to develop the following characteristics: nationalistic, hardworking, creative, environmentally conscious, independent, and cooperative. Students need to maintain these characteristics even after they graduate because these are needed to develop economic sovereignty of their country. Village tourism is chosen in this research because Yogyakarta has a lot of growing tourist villages. Yogyakarta as one of Indonesia's tourism centers can be a model for the development of village tourism. This model can be a future reference for students if they wish to develop village tourism in Indonesia. Based on the interviews conducted in the beginning of the project, most of the students said that they were not aware of the potential of a tourist village for the community's wealth. Problem-Based Learning describes a concrete phenomenon and problems in the community (Gou, 2020; Arantes do Amaral, 2018). By applying this approach in a class, students and teachers can collaborate to find solutions to some concrete problems in the society.

\section{METHOD}

\section{Design}

This study is based on a mixed method research design (Cresswell \& Clark, 2017). While the qualitative analysis was employed to understand the utilization of tourist villages in CE course, the quantitative analysis was used to figure out the students' character building.

\section{Participants}

The participants of this study included 90 Economics Education students who enrolled in a CE course (45 in a private university and 45 in a state university) aged between 18 
and 20 years old, and 3 lecturers (one was teaching and the other two were observing). Upon completion of the university degree, these students will become economics teachers in high school.

\section{Data Collection}

The data collection techniques in this research included observations, interviews, and documentation.

Observation. This step was conducted by the lecturer and the two observers. The object under observation were the students' characteristics. The data were obtained from the notes taken during the class activities both in the classroom and in the fieldwork and interactions with the students. The observation guideline was used to monitor the frequency of students' character-building changes. The frequency was measured by these levels: never (1), rarely (2), sometimes (3), often (4), always (5).

Table 1

The observation guideline

\begin{tabular}{ll}
\hline Characteristics & Indicator \\
\hline Hard working & The initiative, diligence, good setting, resourcefulness (Lickona, 1992) \\
\hline Creative & $\begin{array}{l}\text { The idea to develop village tourism, to find new solutions to a problem (Karwowski, et } \\
\text { al., 2020) }\end{array}$ \\
\hline Nationalistic & $\begin{array}{l}\text { Purchase and use local products rather than imported goods and love the motherland } \\
\text { (Breton, 1964; Nelson, 1976) }\end{array}$ \\
\hline $\begin{array}{l}\text { Environmentally } \\
\text { conscious }\end{array}$ & $\begin{array}{l}\text { No littering, not damage the environment, more respect for natural resources and cultural } \\
\text { heritage (Pane \& Patriana, 2016) }\end{array}$ \\
\hline Independent & $\begin{array}{l}\text { Not depending on somebody else, trying to solve own problems, making efforts to } \\
\text { improve one's attitude (Samani, \& Hariyanto, 2011) }\end{array}$ \\
\hline Cooperative & $\begin{array}{l}\text { Working in team to attain the shared goal and benefit, helping friends in need during the } \\
\text { observation (Gächter, et al., 2010) }\end{array}$ \\
\hline
\end{tabular}

During the initial stage of learning, the lecturer observed the student's apparent attitudes in PBL. The steps in PBL are: 1) Students and lecturer decided the project's theme, goal, design, 2) Students collected information, analyzed the data, presented the findings, and evaluated the project (Van Lam, 2011).

Interview. It is a semi-structured interview done through dialogue, in-person Q\&A with the students. The results of the interview are outlined in the summary. The interview guide consists of 7 questions: advantages, disadvantages of tourism villages as well as the difficulties in implementing tourism villages reflected by residents. The questions include: 1) How is village tourism as a learning resource incorporated into CE courses? 2) Is the use of village tourism as a learning source effective? Why? 3) What are the advantages and disadvantages of using village tourism as a learning resource for students? 4) What facilities are provided by the tourist villages that make them worth visiting by the students? 5) What do the locals say about the use of village tourism for the undergraduate courses? 6) Is there any objection to the use of village tourism as a learning resource for $\mathrm{CE}$ courses? 7) What are the obstacles encountered during the process?

Documentation. Lecturers checked on students' notes which consist of activity journal, transcript from the interview and observation by the students in the field, photos and videos when they were in the tourist village. 


\section{Data Analysis}

This research used the Interactive Analysis model by Miles, et al. (2014) to analyze qualitative data. The procedure included data collection, data reduction, data display, and conclusions. To check for trustworthiness, the data validity test was done through the triangulation of the sources and methods. This research used percentages to present quantitative data. Paired t-test was employed to understand participants' characteristics between at the beginning of the study and at the end of the observation.

\section{FINDINGS}

This section provides the details of the research findings. The discussion includes the explanation about the learning activity, starting from the initial stage up to the analysis based on the classroom observations by the lecturers.

\section{The Learning Activity}

The Initial Stage of Problem Orientation. In groups, students figured out the problems in their tourist villages. In the first meetings, students were divided into a group of 5 . The tourist villages that the students selected are as follow:

Table 2

The list of tourist villages that the students as a group selected

\begin{tabular}{lll}
\hline Group & Name of the tourist village & Features of the tourist village \\
\hline $1 \mathrm{SU}$ & Kembangarum & Nature \\
\hline $2 \mathrm{SU}$ & Sidoakur & Culture \\
\hline $3 \mathrm{SU}$ & Pentingsari & Nature \\
\hline $4 \mathrm{SU}$ & Pulesari & Nature \\
\hline $5 \mathrm{SU}$ & Tembi & Culture \\
\hline $6 \mathrm{SU}$ & Brayut & Culture \\
\hline $7 \mathrm{SU}$ & Kelor & History \\
\hline $8 \mathrm{SU}$ & Kauman & Culture \\
\hline $9 \mathrm{PU}$ & Kotagede & Culture \\
\hline $10 \mathrm{PU}$ & Kasongan & Culture \\
\hline $11 \mathrm{PU}$ & Mangunan & Nature \\
\hline $12 \mathrm{SU}$ & Gamplong & Culture \\
\hline $13 \mathrm{PU}$ & Taman sari & History \\
\hline $14 \mathrm{PU}$ & Kadipaten & Culture \\
\hline $15 \mathrm{PU}$ & Pluneng & Nature \\
\hline $16 \mathrm{PU}$ & Kelor 2 & Nature \\
\hline $17 \mathrm{PU}$ & Rumah Dome & Culture \\
\hline $18 \mathrm{PU}$ & Ngampilan & Culture \\
\hline
\end{tabular}

SU: State University PU: Private University

Before they went to the field, the lecturer and students carefully read the guidelines of village tourism. At the sites, students recorded and documented the results of their survey.

Stage Guiding research /group survey. Students studied the development model of CE, students in the $C E$ book. Students were still confused when being asked to relate the $\mathrm{CE}$ with village tourism. Most of them did not completely fill out the form. The lecturer provided feedback: 
During the stage of developing and presenting the results of the observation. The students present their observation results in front of the class. The meetings in this tourist village can be an example of the development of CE.

The learning activity in each meeting both in and outside of the classroom, findings from the tourist village, activity/method, and characteristics that emerge is described in the following table.

Table 3

The activities during the CE class and characteristics that emerged

\begin{tabular}{|c|c|c|c|c|}
\hline Meeting & Subject matter & Findings in a tourist village & $\begin{array}{l}\text { Activities/ } \\
\text { Methods }\end{array}$ & $\begin{array}{l}\text { Characteristics } \\
\text { that appear }\end{array}$ \\
\hline 1 & $\begin{array}{l}\text { Introduction PBL } \\
\text { and observation } \\
\text { plan }\end{array}$ & $\begin{array}{l}\text { The lecturer explained the course outline of CE course. } \\
\text { Students selected one of } 135 \text { the tourist villages from the } \\
\text { list. }\end{array}$ & $\begin{array}{l}\text { Orientation/ } \\
\text { Discussion }\end{array}$ & $\begin{array}{l}\text { Creative, } \\
\text { Nationalistic }\end{array}$ \\
\hline 2 & $\begin{array}{l}\text { The essence of CE, } \\
\text { the development of } \\
\text { Kembangarum } \\
\text { tourist village }\end{array}$ & $\begin{array}{l}\text { Village tourism can increase people's income. The local } \\
\text { people have managed their tourist village through } \\
\text { ownership, decision making and responsibilities. Students } \\
\text { sought the connection between the course materials on } \\
\text { village development and facts they found in the tourist } \\
\text { village }\end{array}$ & Discussion & $\begin{array}{l}\text { Creative, } \\
\text { Independent }\end{array}$ \\
\hline 3 & $\begin{array}{l}\text { The village tourism } \\
\text { development } \\
\text { model in } \mathrm{CE}\end{array}$ & $\begin{array}{l}\text { Participative Development Model and "padat karya" can } \\
\text { be developed in a tourist village. Village tourism allows its } \\
\text { citizens to develop their village, where local people can } \\
\text { participate in the development by providing homestay, } \\
\text { culinary, tourist guide, and so forth. }\end{array}$ & $\begin{array}{l}\text { Presentatio } \\
n \text { of the } \\
\text { results of } \\
\text { observation }\end{array}$ & $\begin{array}{l}\text { Nationalistic, } \\
\text { Hardworking, } \\
\text { Creative }\end{array}$ \\
\hline 4 & $\begin{array}{l}\text { The policy of CE } \\
\text { and village tourism }\end{array}$ & $\begin{array}{l}\text { The policy should be integrated and wholistic between the } \\
\text { government, village, and village administration. The natural } \\
\text { environment should be preserved. }\end{array}$ & Discussion & $\begin{array}{l}\text { Environmentall } \\
\text { y conscious }\end{array}$ \\
\hline 5 & $\begin{array}{l}\text { Poverty alleviation } \\
\text { in the tourist } \\
\text { village }\end{array}$ & $\begin{array}{l}\text { They concluded that tourist village played an important role } \\
\text { in absorbing the workforce in order to alleviate poverty in } \\
\text { the area }\end{array}$ & Jigsaw & $\begin{array}{l}\text { Nationalistic, } \\
\text { Hardworking, } \\
\text { Creative }\end{array}$ \\
\hline 6 & $\begin{array}{l}\text { The strategy for } \\
\text { CE development }\end{array}$ & $\begin{array}{l}\text { Tourist village in Sidoakur (Sleman Regency) had the } \\
\text { potential to increase the local people's income by providing } \\
\text { culinary, homestay and tourist guide. } \\
\text { It had the potential to increase the local people's income. }\end{array}$ & Discussion & $\begin{array}{l}\text { Hardworking, } \\
\text { Creative }\end{array}$ \\
\hline $7 \& 8$ & $\begin{array}{l}\text { MSMEs in Tourist } \\
\text { Villages }\end{array}$ & $\begin{array}{l}\text { Cooperation among MSMEs, in the village, among } \\
\text { villages, district, regency. They learned that the UMKM in } \\
\text { the area was related to marketing and limited access to } \\
\text { information service as well as lack of education of the local } \\
\text { children. }\end{array}$ & STAD & $\begin{array}{l}\text { Nationalistic, } \\
\text { Creative }\end{array}$ \\
\hline $9 \& 10$ & $\begin{array}{l}\text { Cooperative in } \\
\text { Pulesari tourist } \\
\text { village }\end{array}$ & $\begin{array}{l}\text { The koperasi has not been established formally, but they } \\
\text { already have joint cooperation among Group Tani dusun } \\
\text { (Group Tani Sumber Mulyo), USEPKM (Usaha Ekonomi } \\
\text { Produktif Keluarga Miskin), KUBE (Group Usaha } \\
\text { Bersama). They had a forum called Pokdarwis (Group } \\
\text { Sadar Wisata) at the level of district and regency, so there } \\
\text { was a partnership between tourist village managements }\end{array}$ & $\begin{array}{l}\text { Presentatio } \\
\mathrm{n}\end{array}$ & $\begin{array}{l}\text { Independent, } \\
\text { Cooperative }\end{array}$ \\
\hline $11 \& 12$ & $\begin{array}{l}\text { Empowerment of } \\
\text { the CE in the } \\
\text { tourist village of } \\
\text { Tembi and Brayut }\end{array}$ & $\begin{array}{l}\text { There is participatory APBDes planning (Anggaran } \\
\text { Pendapatan dan Belanja Desa). It is conducted } \\
\text { transparently and equally. }\end{array}$ & Discussion & Cooperative \\
\hline $13 \& 14$ & $\begin{array}{l}\text { The partnership is } \\
\text { related to the } \\
\text { tourist village of } \\
\text { Kelor }\end{array}$ & $\begin{array}{l}\text { Kelor works together with villages located near to Sleman. } \\
\text { Partnership with other tourist villages are visible from how } \\
\text { these villages help and complete each other in culinary, } \\
\text { accommodation, and information }\end{array}$ & $\begin{array}{l}\text { Presentatio } \\
\mathrm{n}\end{array}$ & Cooperative \\
\hline
\end{tabular}

International Journal of Instruction, October $2021 \bullet$ Vol.14, No.4 


\section{Village Tourism as Learning Resources}

Based on in-depth interviews and observation, village tourism can be utilized as the learning resource for a CE course because residents usually offer services to tourists and visitors, such as homestay, handicrafts, culinary, etc. Village tourism can be an effective learning resource for students since they are able to see directly the economic condition run by local people through the presence of tourist villages.

The data from interviews/observations reveal some advantages of incorporating village tourism as a learning resource into a CE course. Students got direct experience and new ideas that could be recommended to the local residents to improve village tourism management. Students got inspiration for their thesis that may make some contribution to village tourism in the future. Besides, students were able to do social analysis and suggested ways to implement what they have learned from village tourism in Yogyakarta to their villages.

For example, students were assigned to identify the problems that arise in tourist villages from CE perspective. Students identified the welfare of the local people who live in the areas. This provided a meaningful learning experience to the students and challenged them to conduct research in village tourism (McConnell \& Marton, 2011).

Direct observations in the tourist village raised student's environmental awareness. This awareness leads to a commitment to constantly make serious efforts to fix the existing natural damages. It also included students' ability to transform wastes into commodities with added values. Hence, village tourism can be a model of CE.

However, direct observation to tourist villages also has disadvantages. First, it is a burden for students because it is very time-consuming due to the distance, bureaucracy issues, etc. It takes more efforts to do the teamwork and to deal with the varying condition of the tourist village. Some villages are not prepared to welcome students doing observation in their area.

As long as village tourism provides students with students' visit room, socialization materials of the village condition, and a chance to do village tour directly, the village's facilities can be categorized as decent or worth visiting. Other facilities that will ideally accommodate visitors' needs are $\mathrm{Wi}-\mathrm{Fi}$, easy access to the village, restaurants and hotels, and strategic location near healthcare centres such as Puskesmas (clinic) or hospitals. This is consistent with the findings of Ma'ruf (2017).

Putting village tourism as the learning resource was supported by local government and residents of the tourist village. Students stated that while they were at the village tourists, they did not find any party who opposed the program. 


\section{Student's Characteristic Development through Problem-Based Learning}

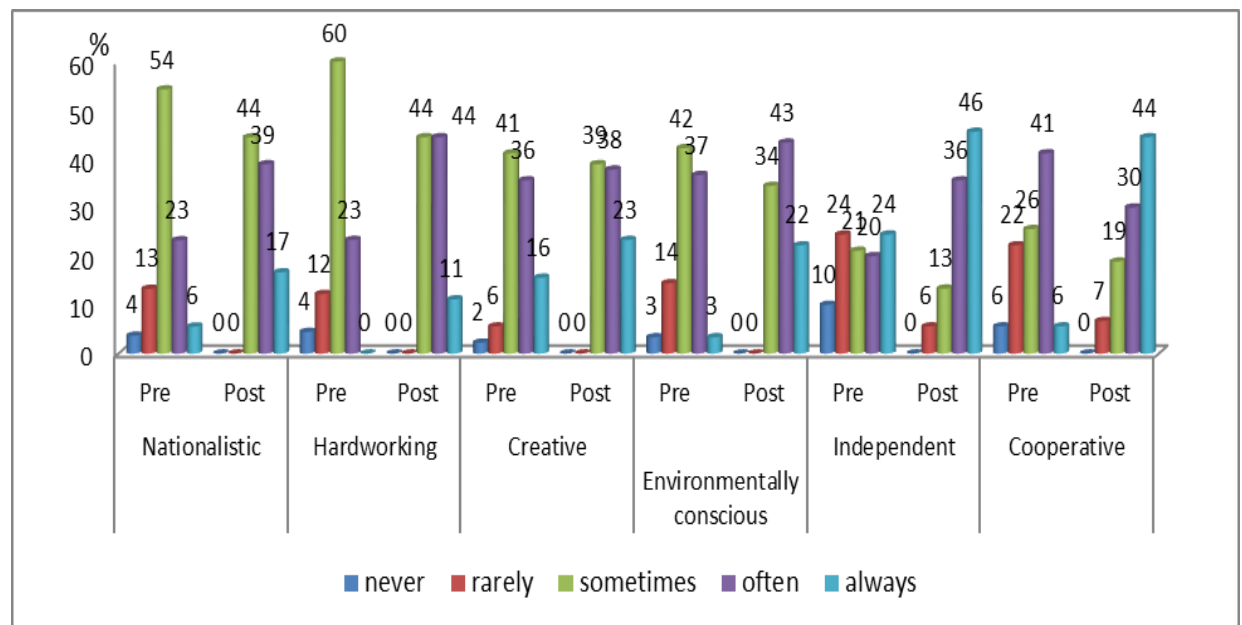

Figure 2

Histogram of characteristic categorization such as nationalistic, hardworking, creative, environmentally conscious, independent, and cooperative at the beginning and the end of the course $(\%)$.

Throughout the learning process, the observers took notes of every detail related to the students' character development. They checked the extent to which each student became more nationalistic, hardworking, creative, environmentally conscious, independent, and cooperative before and after the PBL. Based on the observation, it is found that students' characteristics improved in all categories. For example, after the PBL, students became more proactive and often took initiatives in doing stuffs. Another example is on how they care about the environment. Before the PBL, the students sometimes ignored the cleanliness of the classroom, but then they always voluntarily clean it. This change is also reflected in the t-paired test as follows: 
Table 4

Paired samples statistics

\begin{tabular}{|c|c|c|c|c|c|}
\hline & & Mean & $\mathrm{N}$ & $\begin{array}{l}\text { Std. } \\
\text { Deviation }\end{array}$ & $\begin{array}{l}\text { Std. Error } \\
\text { Mean }\end{array}$ \\
\hline \multirow[t]{2}{*}{ Pair 1} & NationalisticPre & 2.8556 & 90 & .84216 & .08877 \\
\hline & NationalisticPos & 3.7222 & 90 & .73481 & .07746 \\
\hline \multirow[t]{2}{*}{ Pair 2} & Hardworking Pre & 3.0222 & 90 & .73405 & .07738 \\
\hline & Hardworking Pos & 3.6667 & 90 & .67040 & .07067 \\
\hline \multirow[t]{2}{*}{ Pair 3} & Creative Pre & 3.5667 & 90 & .90006 & .09487 \\
\hline & Creative Pos & 3.8444 & 90 & .77765 & .08197 \\
\hline \multirow[t]{2}{*}{ Pair 4} & Environmentally conscious Pre & 3.2222 & 90 & .85824 & .09047 \\
\hline & Environmentally conscious s & 3.8778 & 90 & .74695 & .07873 \\
\hline \multirow[t]{2}{*}{ Pair 5} & Independent Pre & 3.24 & 90 & 1.335 & .141 \\
\hline & Independent Post & 4.21 & 90 & .880 & .093 \\
\hline \multirow[t]{2}{*}{ Pair 6} & Cooperative Pre & 3.19 & 90 & 1.027 & .108 \\
\hline & Cooperative Post & 4.12 & 90 & .946 & .100 \\
\hline
\end{tabular}

In social sciences, the alternative hypothesis is considered significant if the value is less than 0.005 (Johnson, V. E., 2013). In this research, the pair t-test shows a significance of 0.000. Therefore, there is a significant difference in the character of students before and after PBL activities by utilizing tourist villages as a source of economic learning. At the beginning of the course, the lecturer used the observation guidelines to measure the student's characteristic development. From the early data and observation, it can be seen that some students were still at the levels of "rarely" and "never".

At the end of the course, the students become more nationalistic, hardworking, creative, environmentally conscious, independent, and cooperative. For examples, they could perform well in teamwork, appreciate their friends' opinions better, become more fluent and confident in expressing ideas, became more enthusiastic about classroom discussions and more responsible for the assignments. A student said: "I'm becoming more independent when doing my own work with my team. For example, to prepare the documentation of the tourist village. I can't rely on my friends because they have their own work." Students' sense of being cooperative emerged particularly when they did field observation in the assigned tasks and made a presentation describing the results of their observations.

\section{DISCUSSION}

Based on the research findings, it can be concluded that the frequency of characteristics increased. It indicates that there was an improvement in the efforts to raise the sense of nationalism. This is reflected in students' activities during the teaching-learning process: 1) After looking at other sources, students understand that tourist village in Indonesia is beautiful and thus having potential, 2) Students became proud of their own cultural heritage, natural resources, and village history 3) Students were proud to develop villages in Indonesia. 
The data also show that there is an improvement in student's hardworking and creative categories Again, it is in accordance with the research findings by (Parrado-Martínez \& Sánchez-Andújar, 2020).

Some students said that they saw, "the tourist village community leaders working hard to make their village more attractive for tourism. This experience inspires me to work hard."

The data show that students are becoming more hardworking after the PBL. This is reflected on the students' activity in their learning process such as 1) Students have plan to develop the tourist village in their hometown to improve the economy 2) Tourist village makes students think more creatively, 3) Students have ideas to develop new tourist villages 4), Students are confident that they could overcome the challenges when they are building the tourist village in their area, and 5) During the observation, students must deal with bureaucracy and they were keen on coming to the tourist villages until they meet the informants or the staff of the tourism village in person.

The effort to raise environmental awareness is increasing. It is reflected in the student's activities during the learning process: 1) Students argue that tourist village must be developed in accordance with the environment, 2) Once the students understand the reasons why tourist village is important, they love environment better, 3) Students believe that clean environment can provide more economic values for local people, 4) Students believe that used goods such as handycrafts from recycled materials have economic values if they are managed properly. These findings aligned with those of Rahmatullah (2016) and Genc (2015).

The findings of this research show that village tourism can be integrated with the materials for a CE course, particularly the PBL method. It may also develop a student's characteristics (Perrault \& Albert, 2018). It is to enrich students' experience, which is also in line with Arantes do Amaral et al. (2018) and Wijiningsih et al. (2017). Besides, this course helped students to improve their abilities to overcome obstacles in developing village tourism, to convince the local people to take part in developing the tourist village, and to design projects that would be beneficial to both students and villagers whose area has tourism potential. It is in line with the study by Kizkapan \& Bektas (2017).

PBL method for this class allows students to be more critical towards issues related to village tourism in Indonesia.

Tourist village can be an interesting learning resource as photos and videos that they took during the observation can be used as learning media for them in the future when they teach. It is in line with researches by Vazquez \& Chiang (2014) and Vidal, et.al (2020). This activity will lead to a better and fun learning outcome.

The learning process can be challenging due to the complexity of problems and students' lack of interest (Ball \& Pelco, 2006). That is why this study is beneficial for curriculum designers, as it can be a model for developing a CE course that is concerned with both tourism village and youth's involvement in its development. Characteristics 
developed through this course are expected to be a human resource capital for national tourism development.

\section{CONCLUSION}

This research shows how village tourism is potentially incorporated into a CE course by implementing PBL. It can be used as learning media during the student's pre-service teaching and in the future when they teach their own class. The materials related to the $\mathrm{CE}$ course can be integrated into such themes as the core concept of CE, village development, the CE development model, poverty alleviation, Micro Small-Medium Enterprise (MSMEs), and village tourism, the empowerment of CE, and partnership.

Village tourism as a learning resource may also contribute to students' characteristic development in terms of nationalism, hardworking ethos, creativity, and environmental awareness, independence, and cooperation. These characteristics are needed to enhance student's personal and professional development especially in this globalization era. This model is potential to be applied in other courses with similar goal, that is, to develop tourist villages across the country. It is important to be taught because most Indonesian population live in the village, and village tourism has high economic value which is beneficial to increase the GDP.

This project can serve as a sample learning model for teaching CE which incorporates the local tourism into a college course and makes college learning experiences more meaningful. Students in the future can also apply this method in high schools where they teach. That way, this project is sustainable and has multiplier effect for their students.

This study can be a baseline for Dikti (Ministry of Higher Education) to develop CE course at the university level. Many studies have been done on ecotourism and village tourism, but none of those was used as a learning resource for CE courses at the Faculty of Economics across universities in Indonesia. In Indonesia, small-medium enterprise and rural economy is important because it is very crucial in Indonesian economic. It is recommended that Dikti offers greater research opportunities which is concerned with community economy and sustainable development.

\section{ACKNOWLEDGEMENT}

The authors received research funding support from Kementerian Pendidikan dan Kebudayaan Indonesia.

\section{REFERENCES}

Agussalim, Mintarti Widjaja, S. U., Haryono, A., \& Wahyono, H. (2021). Pancasila economic character literacy program for high school students. International Journal of Instruction, 14(1), 235-252. https://doi.org/10.29333/iji.2021.14114a

Akbulut, B., \& Adaman, F. (2020). The Ecological Economics of Economic

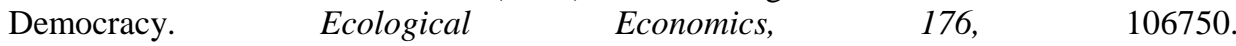
https://doi:10.1016/j.ecolecon.2020.106750 
Arantes do Amaral, J. A., dos Santos, L., \& Rodrigues, R. J. (2018). Combining projectbased learning and community-based research IN A research methodology course: The Lessons Learned. International Journal of Instruction, 11(1), 47-60. doi: 10.1080/09650792.2016.1147368.

Aref, F., \& Gill, S. S. (2009). Rural tourism development through rural cooperatives. Nature and Science, 7(10), 68-73.

Arida, N. S., Suryasih, I. A., \& Parthama, I. G. N. (2019, August). Model of community empowerment in tourism village development planning in Bali. In IOP Conference Series: Earth and Environmental Science, 313, p. 012024. IOP Publishing. doi:10.1088/1755-1315/313/1/012024

Awang, S. A.Radhi., Baswir, R., Santoso, A., Priyono, A., Kusumawardhani, D., Hudiyanto, Wibowo, I. A., Indroyono, P. (2012). Pengembangan Model Inkubator CE di Desa-Desa Miskin Sekitar Hutan: Studi Kasus di kabupaten Gunung Kidul Yogyakarta: Pustek UGM

Ball, C. T., \& Pelco, L. E. (2006). Teaching research methods to undergraduate psychology students using an active cooperative learning approach. International Journal of Teaching and Learning in Higher Education, 17(2), 147-154.

Bapeda. (2021). Aplikasi dataku Daerah Istimewa Yogyakarta. Bidang pariwisata Retrived From: http://bappeda.jogjaprov.go.id/dataku/data_dasar/index/211pariwisata?

id_skpd=23

Baroroh, K, Lestari, B., Suwarno. (2011). The implementation of simulation method and the use of used goods as teaching media: a strategy to develop student's character in CE course), A Research Report. FE UNY.

Berkes, F. 2009. Evolution of Co-management: Role of knowledge generation, bridging organization and social learning. Journal of Environmental Management, 16921702 doi: 10.1016/j.jenvman.2008.12.001

Boy, J. K. N., Djinar, S. N., Urmila, D. M. H., \& Marhaeni, A. A. I. N. (2019). The effect of stakeholders on village community creativity and community welfare of coastal village in The Bali Province, Indonesia. Russian Journal of Agricultural and SocioEconomic Sciences, 93(9), 206-215.

Couret-Branco, M. (2016). Economics for substantive democracy. Review of Social Economy, 74(4), 369-389. doi: /10.1080/00346764.2016.1171382

Creswell, J. W. \& Clark, V. L. P. (2017). Designing and conducting mixed methods research. Sage publications.

Doppelt, Y. (2003). Implementation and assessment of project-based learning in a flexible environment. International journal of technology and design education, 13(3), 255-272. doi: 10.1023/A:1026125427344 
Dorobantu, M. R., \& Nistoreanu, P. (2012). Rural Tourism and Ecotourism-the Main Priorities in Sustainable Development Orientations of Rural Local Communities in Romania: effective use of visuals in the economics classroom. International Review of Economics Education, 17, 109-119.

Eugenio-Martin, J. L., Martín Morales, N., \& Scarpa, R. (2004). Tourism and economic growth in Latin American Countries: A Panel Data Approach. Social Science Research Network Electronic Paper Collection. The Fondazione Eni Enrico Mattei Note di Lavoro Series Index. Retrieved from: http://www.feem.it/Feem/Pub/Publications/WPapers/default.htm

Fayissa, B., Nsiah, C., \& Tadasse, B. (2008). Impact of tourism on economic growth and development in Africa. Tourism Economics, 14(4), 807-818.

Gächter, S., Nosenzo, D., Renner, E., \& Sefton, M. (2010). Who makes a good leader? Cooperativeness, optimism, and leading-by-example. Economic Inquiry, 50(4), 953967.doi: 10.1111/j.1465-7295.2010.00295.x

Genc, M. (2015). The project-based learning approach in environmental education. International Research in Geographical and Environmental Education, 24(2), 105-117.

Guo, P., Saab, N., Post, L. S., \& Admiraal, W. (2020). A review of project-based learning in higher education: Student outcomes and measures. International Journal of Educational Research,102, 101586.

Haryanto, J.T. (2014). Model ekowisata dalam mendukung kemandirian ekonomi daerah studi kasus provinsi DIY. Kawistara, 4(3), 225-330.

Herawati, A., Purwaningsih, A., \& Handharko, Y. D. (2018). Promoting village tourism through the development of information systems. Review of Integrative Business and Economics Research, 7, 221-236.

Hermawan, H. (2016). Dampak pengembangan tourist village Nglanggeran terhadap ekonomi masyarakat local. Jurnal Pariwisata, 3(2), 105-117. doi: 10.31311/par.v3i2.1383.

Jacobson, S.K., Robles, R. (1992). Ecotourism, sustainable development, and conservation education: Development of a tour guide training program in Tortuguero, Costa Rica. Environmental Management, 16, 701-713. doi: 10.1007/BF02645660

Johnson, V. E. (2013). Revised standards for statistical evidence. Proceedings of the National Academy of Sciences, 110(48), 19313-19317.

Johanisova, N., \& Wolf, S. (2012). Economic democracy: A path for the future? Futures, 44(6), 562-570. doi: 10.1016/j.futures.2012.03.017

Kizkapan, O., \& Bektas, O. (2017). The Effect of Project Based Learning on Seventh Grade Students' Academic Achievement. International Journal of Instruction, 10(1), 37-54. 
Kolesnikova, A., Maslova, A., \& Mishieva, E. (2020). Peer Assessment in L2 Pronunciation Instruction in Russia: Students' Attitude Research. IAFOR Journal of Education: Language Learning in Education, 8(1). https://doi.org/10.22492/ije.8.1.08

Lickona, T. (1992). Educating for character: How our schools can teach respect and responsibility. Bantam.

Limbong, F., \& Soetomo, S. (2013). Dampak Perkembangan Pariwisata Terhadap Lingkungan Taman Nasional Karimunjawa. Ruang, 2(1), 51-60.

Ma'ruf, A. (2017). Optimization of social capital on management of ecotourism's infrastructure. Asia Pacific Journal Of Advanced Business And Social Studies.McConnell, W., \& Marton, J. P. (2011). Introducing students to social science research. Transformative Dialogues: Teaching \& Learning Journal, 5(1), 1-9.

Miles, M. B., Huberman, A. M., \& Saldaña, J. (2014). Qualitative data analysis: A methods sourcebook. 3rd. London: SAGE

Miller, G. Rathouse, K, Scarles, C. Holmes, K. Tribe, J. (2010). Public understanding of sustainable tourism. Annals of Tourism Research, 37(3), 627-645. doi: 10.1016/j.annals.2009.12.002

Mubyarto (2005). A Development Manifesto. The Resilience of Indonesian Ekonomi Rakyat During The Monitory Crisis. Jakarta: Kompas.

Nelson, Jack L. (1976). Nationalistic Vs. Global Education: An Examination of National Bias in the Schools and its Implications for a Global Society. Theory \& Research in Social Education, 4(1), 33-50. doi:10.1080/00933104.1976.10505982

Nizar, M. A. (2011). Pengaruh Pariwisata Terhadap Pertumbuhan Ekonomi Di Indonesia [Tourism Effect on Economic Growth in Indonesia] (No. 65628). University Library of Munich, Germany

Nurtanto, M., Fawaid, M., \& Sofyan, H. (2020). Problem Based Learning (PBL) in Industry 4.0: Improving learning quality through character-based Literacy Learning and Life Career Skill (LL-LCS). Journal of Physics: Conference Series, 1573(1), p. 012006. IOP Publishing.

Parrado-Martínez, P., \& Sánchez-Andújar, S. (2020). Development of competences in postgraduate studies of finance: A project-based learning (PBL) case study. International Review of Economics Education, 35, 100192.

Perrault, E. K., \& Albert, C. A. (2018). Utilizing project-based learning to increase sustainability attitudes among students. Applied Environmental Education \& Communication, 17(2), 96-105. doi: /10.1080/1533015X.2017.1366882

Phiri, A. C. (2016). Tourism and economic growth in South Africa: Evidence from linear and nonlinear cointegration frameworks. Retrieved from https://repository.nwu.ac.za/handle/10394/23776 
Putri, A. M. D., Sri, B. M. K., Suyana, U. M., \& Murjana, Y. I. G. (2019). The influence of government role, community participation and social capital on the quality of destination and community welfare in the tourism village of Badung Regency Province of Bali. Russian Journal of Agricultural and Socio-Economic Sciences, 92(8), 235-251.

Rahmatullah, Wahjoedi, Suman, A., \& Wahyono, H. (2016). Eco Culture Pancasila Values and Its Implementation in Economic Learning. IOSR Journal of Research \& Method in Education, 6(2), Ver.II:2320-7388 (Online).

Rina, L., Murtini, W., \& Indriayu, M. (2018). Establishment of entrepreneurial character in the foundation-based school system through project based learning. International Journal of Educational Research Review, 3(4), 128-140.

Romadhon, A (2013). Pengembangan wisata secara berkelanjutan berbasis kelembagaan di Gugus Pulau Sapeken. Proceeding Seminar Nasional Ekowisata. Nopember 2013. ISBN: 978-602-14594-0-9 Fakultas Pertanian Universitas Widyagama Malang.

Samani, M., \& Hariyanto, M. S. (2011). Konsep dan model pendidikan karakter. Bandung: PT Remaja Rosdakarya.

Satria, D. (2009). The Strategy for the Development of Local Economics-Based Ecotourism in the Context of Poverty Alleviation Program. doi: 10.21776/ub.jiae.2009.003.01.5

Shuqiang, C. Z. Z. (2009). Advantages and disadvantages of tourism development to traditional village scene: Taking the Area around Erhai Lake in Dali as the example. Huazhong Architecture, 3.

Swasono, S. E. (2018). Demokrasi Ekonomi: Doktrin Ekonomi Nasional dalam buku Ekonomi dan keindonesiaa. Membangun ekonomi rakyat. Yogyakarta: UST Press

Swasono, S. E. (2019). Mutualism \& Brotherhood: Dimensi moral ekonomi konstitusi kita. Yogyakarta: Aditya Media

Syafiudin, Sumarmi, \& Astina (2016). Pengembangan Modul Geografi Pariwisata dengan Project Based Learning untuk Materi Ekowisata Pesisir dan Laut di Program Studi S1 Pendidikan Geografi Universitas Negeri Malang. Jurnal Pendidikan: Teori, Penelitian, dan Pengembangan, 1 Mar. 2016, pp. 347-353, doi: 10.17977/jp.v1i3.6160

Van Lam, N. T. (2011). Project-based learning in teaching English as a foreign language. VNU Journal of Foreign Studies,27(2).

Vazquez, J. J., \& Chiang, E. P. (2014). A picture is worth a thousand words (at least): The effective use of visuals in the economics classroom. International Review of Economics Education, 17, 109-119.

Vidal, D. D., Mungenast, K., \& Vidal, J. D. (2020). Economics through film: Thinking like an economist. International Review of Economics Education, 100186.doi:10.1016/j.iree.2020.100186. 
Wang, J., Huang, X., Gong, Z., \& Cao, K. (2020). Dynamic assessment of tourism carrying capacity and its impacts on tourism economic growth in urban tourism destinations in China. Journal of Destination Marketing \& Management, 15. DOI : 10.1016/j.jdmm.2019.100383

Wijiningsih, N., Wahjoedi, W., \& Sumarmi, S. (2017). Pengembangan Bahan Ajar Tematik Berbasis Budaya Lokal. Jurnal Pendidikan: Teori, Penelitian, dan Pengembangan, 2(8), 1030-1036. doi: 10.17977/jptpp.v2i8.9760.

Wulandari, D., Narmaditya, B.S., Wahjoedi, Utomo, S.H., Witjaksono, M., Hardinto, Prih., \& Magistyo P. Priambod. (2017). Factors Affecting Students in Choosing Community Economy in Development Economics Program, Universitas Negeri Malang. International Journal of Economic Research, 14(6).

Zhang, X. (2012). Research on the development strategies of rural tourism in Suzhou based on SWOT analysis. Energy Procedia, 16, 1295-1299. 